\title{
HOUSEHOLD COPING STRATEGIES IN FACING INFIDELITY
}

\author{
Ririhena Lolita L.*, Sapulette Alce Albartin \\ State Christian Institute of Ambon, Indonesia \\ *E-mail: lolita.ririhena@gmail.com
}

\begin{abstract}
The phenomenon that often occurs today in marriage is infidelity. Cases of infidelity in marriage resulting in divorce continue to increase from year to year; throughout 2007, infidelity caused 10,444 divorces to occur out of a total of 15,771 divorce cases in Indonesia. In 2010 cases of infidelity also increased to 20,199 cases. The purpose of this study was to determine the coping strategies and subjective well-being of victims of infidelity. The research method used is a descriptive qualitative method with a case study approach. The respondents in this study used purposive sampling. The data collection method is through interviews and observations. Data analysis techniques used are data reduction, data presentation, and conclusions. The results showed that the coping strategy carried out by families experiencing infidelity was to increase family resilience, especially psychological resilience. Women and men experience the most dominant negative emotion is anger. $A$ family is experiencing infidelity. Both need social support, and they are oriented towards spiritual support. Both men and women experience stress in dealing with their partner's infidelity and reduce tension/pressure with various strategies.
\end{abstract}

\section{KEY WORDS}

Coping strategy, infidelity, strategy, marriage.

One of the signs of a well-organized family is the unity of the members who communicate with each other and carry out their respective roles well ( Puspitawati 2013). Families that do not have unity or are not well organized can lead to family divisions, namely divorce (Puspitawati 2013). Structural, functional views that the high rate of divorce and the increasing number of single parents reflect the breakdown of the family institution. Damage to family institutions is a significant problem in the emergence of other social problems. Previous research has shown that socioeconomic status, such as education, income, and employment status, is inversely related to divorce rates (Norton \& Glick 1979). Jalovaara (2003) explains that couples with the lowest levels of education have a lower risk of infidelity than previous studies had expected. The impact of infidelity is generally felt positively in couples who feel lucky. One of the negative impacts caused by infidelity is the decline in welfare. The conflict between parents is one factor that increases the risk of infidelity (Drozd, $L$ 2016). The conflict between parents may become more pronounced for young people after a divorce than for married families (Grych, 2005). Infidelity has an impact on the high or low welfare of the couple. One analysis revealed that divorced and older couples negatively impact men's health than women (Williams \& Umberson 2004). In addition, infidelity also hurts women's mental, physical, and economic well-being (Smock 1994) and hurts men's family relationships (Seltzer 1991), social networks, and integration (Gerstel et al. 1985). In the condition of a divorced family, significant changes not only have an impact on the couple's relationship but also on the couple's social network. For example, when a couple divorces, many couples lose friends due to changing places of residence (Wang \& Amato 2000). In addition, social networks are also influenced by the individual's age, which is known from the results of previous studies. Previous studies have also shown that older individuals have fewer friends than younger individuals, even though older individuals are much closer. The orientation that can be explained in the relationship of older individuals is to invest the time they have by deepening and maintaining relationships that have been established because they realize that their physical condition is not what it was when they were younger (Cartensen et al. 1999). As for the sex of the partner, it is known that infidelity increases 
depression in women more than men (Marks \& Lambert 1998). This general condition requires the Church's pastoral care strategy to be effective in a changing society. In dealing with the problem, the family performs a coping strategy by utilizing the available resources. According to Friedman (1998) in Rachmawati (2010), coping strategies are positive efforts or behavior as a family response to specific events and events experienced to resolve and solve problems faced.. Differences in the resources owned by the family result in differences in the ability of the family to carry out coping strategies. According to Lazarus and Folkman (1984), coping strategies can be carried out in two ways, namely problem-centered coping strategies and emotion-centered coping strategies. Coping strategies carried out by the family depend on the problems faced, the existing sources of stress, and the resources owned by the family (Maryam 2020). Coping strategies have been identified as typical methods for managing stress ( Skinner, E 2003). Coping strategies carried out by the family will determine the resilience of a family. Family resilience is the family's ability to manage resources and problems to achieve family goals, namely a prosperous family. Family resilience includes physical resilience, social resilience, and psychological resilience (Sunarti 2001). The factors that influence family resilience include the length of education, length of the marriage, income per capita, wife's education, husband's education, family size, age readiness for marriage, social support, quality of gender relations, management of family resources, the productivity of married couples in earn a living (Fitriani 2010, Herawati 2011,). Of course, efforts in this direction require an internal map as an initial step for pastoral assistance. For this reason, specific research is needed to describe the situation/condition in marriage with all the strengths and weaknesses that exist in it before pastoral mapping is carried out. Problems that arise in marriage are natural. However, the problem is how do individuals/married couples deal with the problem? This question is essential to be studied scientifically and systematically, especially about the prevalence of infidelity cases.

\section{METHODS OF RESEARCH}

The relevant paradigm as the research foundation used in this study is the constructivism paradigm. The constructivism paradigm aims to reach a consensus or at least a negotiating agenda on various issues and topics that explain the nature of research (Denzyme 2009). The research approach used is qualitative. This approach was chosen considering that researchers can understand (verstehen) the process, meaning of infidelity, and coping strategies through a qualitative approach. This research was carried out in Ambon. The data collection techniques used were observation, interviews, snowball sampling technique, and documentation study. The validity of the data was carried out using triangulation techniques from sources, methods, investigators, and theories (Denzin \& Lincoln, 2011: 604-606). Data analysis techniques are data collection, data analysis, data reduction, data presentation, and concluding (Creswell. 2010).

\section{RESULTS AND DISCUSSION}

Coping strategies can not be separated from stress and emotions. Understanding effective coping requires us to consider the context of the stressor (Kalokerinos, \& Williams, 2018). This discussion of coping consists of several essential parts for data analysis, namely the exposure of the identity of the research subjects (names withheld), the symptoms of stress experienced, the emotions that appear dominantly, and the coping strategies of each subject in each group of research subjects.

From the research results, it is generally concluded that stress on women ( explicitly in the case of Vita, Tasha, and Ellen, implicitly in the case of Leni) is much greater than stress that occurs in men (Remy, Eky, Yan, John). Women experience severe physical symptoms due to stress on emotions and thoughts), while men experience almost no significant disturbances as experienced by women. Men only have sleep disturbances. Interestingly, there is specificity between the cases of John (the left behind) and Leni (the left behind), who are action-oriented to problem-focused coping. Although both parties are motivated by love, 
there is a significant difference in the level of stress experienced. This is because the endurance of men is different from that of women.

Table 1 - Symptoms of stress experienced by women (the left behind)

\begin{tabular}{|c|c|c|c|}
\hline \multirow{2}{*}{$\begin{array}{l}\text { Subject } \\
\text { Name }\end{array}$} & \multicolumn{3}{|l|}{ Stressful Syndrome Experience } \\
\hline & Physic & Thought & Emosision \\
\hline Leny & - & - & restless, worries, sad, feelingisolated \\
\hline Vita & $\begin{array}{lrr}\text { Indigestion, } & \text { dizziness, } & \text { sleep } \\
\text { disturbances, } & \text { headache } & \text { and } \\
\text { muscle aches } & & \\
\end{array}$ & $\begin{array}{l}\text { Slow thinking, } \\
\text { confused, hard to } \\
\text { concentrate }\end{array}$ & $\begin{array}{l}\text { Restless, worried, afraid, sad, depressed, feeling } \\
\text { abandoned, wanting to hide, wanting to limit contact } \\
\text { with other people, angry, irritable. }\end{array}$ \\
\hline \multirow[t]{2}{*}{ Tasha } & $\begin{array}{l}\text { Trembling (lips, hands), chest } \\
\text { pain, fast heart rate, sleep } \\
\text { disturbances, headache and } \\
\text { muscle aches. }\end{array}$ & $\begin{array}{l}\text { Difficulty } \quad \text { making } \\
\text { decisions, } \\
\text { dreams }\end{array}$ & $\begin{array}{l}\text { Restlessness, worry, guilt, sadness, feeling } \\
\text { abandoned, worried about others, wanting to hide, } \\
\text { wanting to limit contact with other people, angry, } \\
\text { irritable, easily startled or shocked }\end{array}$ \\
\hline & $\begin{array}{l}\text { Chills, chest } \begin{array}{c}\text { pain, } \\
\text { disturbances, sleep } \\
\text { muscle aches. }\end{array} \\
\text { headache }\end{array}$ & $\begin{array}{l}\text { Difficulty making } \\
\text { decisions, difficult in } \\
\text { problem solving }\end{array}$ & $\begin{array}{l}\text { Fear, sadness, depression, feeling abandoned, } \\
\text { angry, irritable. }\end{array}$ \\
\hline Ellen & $\begin{array}{l}\text { Chills, chest } \begin{array}{c}\text { pain, } \\
\text { disturbances, sleep } \\
\text { muscle aches. }\end{array} \\
\text { headache }\end{array}$ & $\begin{array}{l}\text { Difficulty making } \\
\text { decisions, difficult in } \\
\text { problem solving }\end{array}$ & $\begin{array}{l}\text { Fear, sadness, depression, feeling abandoned, } \\
\text { angry, irritable. }\end{array}$ \\
\hline
\end{tabular}

The results showed that women's resistance to stress was much more significant and more prolonged than men's when their partners cheated on them. Women can survive for years, while men are not. However, men accept their wives more quickly than women accept their husbands in their exclusive relationship. Women cannot simply ignore their husbands, as seen in all-male subjects in this study. Unlike men, women will wrestle with all their strength. In a situation like this, women do not give up. Women are very active in solving problems while men seem not to act much. From the study results, it appears that male subjects are more easily frustrated and discouraged than women. A sense of helplessness paralyzes men. They chose to be indifferent. That is why men tend to be oriented towards emotional regulation in their coping behavior when experiencing traumatic situations like this because they judge that the situation is beyond their control. Another exciting thing that was also found was that being jealous of women caused them not to share their husbands with other women. When this happens, women tend to feel disgusted, causing disturbances when having sex with their husbands (Vita, Tasha, Ellen, except for Leni). In contrast to women, men generally have a great acceptance of cheating wives. This is due to the absence of jealousy in men towards third persons compared to women's case. Although the men who were the subjects of this study did not talk about their sexual life at all, it can be concluded that the ability to accept the presence of the wife again indicates the absence of disgust as commonly experienced and shown by female subjects in this case. It was found further from this study that there were differences related to traumatic responses in men and women. Trauma to men seems to cause great anxiety not only because of the loss of trust (explicitly in the case of Remy, Eky, and Yan, implicit in John's case) but also because of a sudden change in future orientation also feel cheated. Loss of trust makes it difficult for them to trust their wife, and even though they accept her back in their lives (except for the case of Eky), it is overshadowed by the fear of being hurt again (Verbatim data, confessions of Remy, Eky, and Yan). However, the psychosomatic impact of stress experienced by male subjects seemed lighter than that experienced by female subjects in similar cases. From the table data, it is known that trauma to women causes high anxiety (explicitly in Vita, Tasha, and Ellen, implicit in the case of Leni) because they are in a struggle and love competition. That is why it is not easy for women to accept reality as long as there is hope in their assumptions to regain their husbands' affection. In addition, Ross et al. (1990) explained that the contribution of work for both women and men could impact reducing levels of depression, disappointment, and psychological distress. In terms of gender differences, the impact of separation and divorce has a more significant stress effect on married and unmarried women. In addition, the results of previous studies also found that divorce has more impact on psychological well-being in women than men. This is evidenced by the high-stress level of women, while their happiness is lower than that of men, in line with divorce. 
Family coping strategies are behavioral responses and actions taken by families to solve problems faced due to family life due to infidelity.

Table 2 - Women's coping strategies (the left behind)

\begin{tabular}{|c|c|c|c|c|c|c|c|c|}
\hline \multirow{2}{*}{ Name } & \multicolumn{3}{|c|}{ Problem solving coping } & \multicolumn{5}{|c|}{ Emotion focused coing } \\
\hline & Plan prob. solv & Conf. Cop. & Seek soc.sup & Self cont & Dist. & Esc.av & Accep.resp & Pos. reap \\
\hline Leny & $\bullet$ & $\bullet$ & & $\bullet$ & & & $\bullet$ & $\bullet$ \\
\hline Vita & $\bullet$ & $\bullet$ & $\bullet$ & $\bullet$ & $\bullet$ & & $\bullet$ & $\bullet$ \\
\hline Tasha & $\bullet$ & $\bullet$ & $\bullet$ & $\bullet$ & & & $\bullet$ & $\bullet$ \\
\hline Ellen & $\bullet$ & $\bullet$ & $\bullet$ & $\bullet$ & & & $\bullet$ & $\bullet$ \\
\hline
\end{tabular}

Table 3 - Strategy coping men (the left behind)

\begin{tabular}{|c|c|c|c|c|c|c|c|c|}
\hline \multirow{2}{*}{ Name } & \multicolumn{3}{|c|}{ Problem solving coping } & \multicolumn{5}{c|}{ Emotion focused coping } \\
\cline { 2 - 8 } & Plan. prob. solv. & Conf. cop. & Seek. soc. sup. & Self cont. & Dist. & Esc.av & Accp. resp. & Pos. reap \\
\hline Remy & & $\bullet$ & $\bullet$ & $\bullet$ & & $\bullet$ & $\bullet$ & ・ \\
\hline Eky & $\bullet$ & $\bullet$ & $\bullet$ & $\bullet$ & & $\bullet$ & $\bullet$ & $\bullet$ \\
\hline John & $\bullet$ & $\bullet$ & $\bullet$ & $\bullet$ & & $\bullet$ & $\bullet$ & $\bullet$ \\
\hline Yan & $\bullet$ & $\bullet$ & $\bullet$ & $\bullet$ & & & $\bullet$ & $\bullet$ \\
\hline
\end{tabular}

This study indicates that all-female subjects then perform an emotion-centered coping strategy after all attempts to solve the problem have been judged to have failed. The initial strategy is no longer repeated, and they decide to continue to build a life by finding meaning in the presence of children. The Vita subject also did this last thing, who previously almost killed himself because he felt rejected and depressed. In the planful problem-solving strategy, all-male subjects generally look for evidence to confirm the suspicion that their wife is cheating on them. However, the subject of Remy does not explicitly state this because he does not take any action until he finds out the facts for himself. In the form of confrontative coping, all-male subjects, after obtaining evidence of wife's infidelity, generally gave advice aimed at convicting. Except for the subject of Remy, who directly hit his wife in front of his rival, and on another occasion, reproached his wife verbally for choosing someone else's husband. In seeking social support, all subjects did not seem to actively seek social support, except for John, who presented Babinsa and government staff only to prove the validity of their marital status in front of the community. However, in general, all subjects had contacted the Pastor to pray for them (John, Remy) or received attention and support from the people around them, including the Pastor (Yan, Eky). From the table above, it is also known that in general, men choose the avoidance-escape strategy by drinking coffee at the beginning of a difficult adjustment, and after that, they try to control their emotions and actions so that the situation/condition becomes better than before. Meanwhile, women generally take a selfcontrolling approach when they repeatedly fail in problem-solving-oriented strategies to deal with their husband's infidelity. This fact proves that both women and men who survive need a supportive social environment in difficult times, even though meeting these needs differs significantly in their actualization.

\section{CONCLUSION}

Coping strategies carried out by families experiencing infidelity are to increase family resilience, especially psychological resilience. Women and men experience the most dominant negative emotion is anger. A family experiencing infidelity both need social support, and they are oriented towards spiritual support. Both men and women experience stress in dealing with their partner's infidelity and reduce tension/pressure with various strategies.

\section{REFERENCES}

1. Compas, B. E., Connor-Smith, J. K., Saltzman, H., Thomsen, A. H., \& Wadsworth, M. E. (2001). Coping with stress during childhood and adolescence: problems, progress, and potential in theory and research. Psychological bulletin, 127(1), 87-127. 
2. Denzin, N. K., \& Lincoln, Y. S. (Eds.). (2011). The Sage handbook of qualitative research. Sage.

3. Fung, H. H., Carstensen, L. L., \& Lutz, A. M. (1999). Influence of time on social preferences: Implications for life-span development. Psychology and aging, 14(4), 595.

4. Grych, J. H. (2005). Interparental conflict as a risk factor for child maladjustment: Implications for the development of prevention programs. Family Court Review, 43(1), 97-108.

5. Herawati, T., Sugihen, B. G., Asngari, P. S., Susanto, D., \& Puspitawati, H. (2011). Manajemen Sumberdaya Keluarga Peserta Program Pemberdayaan Masyarakat di Kabupaten Bogor. Jurnal Penyuluhan, 7(2).

6. Jalovaara, M. (2003). The joint effects of marriage partners' socioeconomic positions on the risk of divorce. Demography, 40(1), 67-81.

7. Marks, N. F., \& Lambert, J. D. (1998). Marital status continuity and change among young and midlife adults: Longitudinal effects on psychological well-being. Journal of family issues, 19(6), 652-686.

8. Miles, M. B., Huberman, A. M., \& Saldaña, J. (2018). Qualitative data analysis: A methods sourcebook. Sage publications. Drozd, L., Saini, M., \& Olesen, N. (Eds.). (2016). Parenting plan evaluations: Applied research for the family court. Oxford University Press.

9. Maryam, S. (2020). Strategi coping keluarga yang terkena musibah gempa dan tsunami di provinsi nanggroe aceh darussalam. World, 11.

10. Norton, A. J., \& Glick, P. C. (1979). Marital instability in America: Past, present, and future. Divorce and separation. New York: Basic Books.

11. Puspitawati, H., Ma'mun Sarma, T. H., \& Muflikhati, I. (2019). Bunga rampai pendidikan keluarga berwawasan gender. PT Penerbit IPB Press.

12. Rachmawati, A. (2010). Strategi Koping dan Faktor-faktor yang Mempengaruhi Kesejahteraan.

13. Subjektif pada Keluarga Penerima Program PKH. Bogor: Institut Pertanian Bogor.

14. Skinner, E. A., Edge, K., Altman, J., \& Sherwood, H. (2003). Searching for the structure of coping: a review and critique of category systems for classifying ways of coping. Psychological bulletin, 129(2), 216-269. https://doi.org/10.1037/00332909.129.2.216.

15. Sunarti, E., Nuryani, N., \& Hernawati, N. (2009). Hubungan antara fungsi adaptasi, pencapaiantujuan, integrasi, dan pemeliharaan sistem dengan kesejahteraan keluarga. Jurnal Ilmu Keluarga \& Konsumen, 2(1), 1-10.

16. Smock, P. J. (1994). Gender and the short-run economic consequences of marital disruption. Social forces, 73(1), 243-262.

17. Seltzer, J. A. (1991). Relationships between fathers and children who live apart: The father's role after separation. Journal of Marriage and the Family, 79-101.

18. Wang, H., \& Amato, P. R. (2000). Predictors of divorce adjustment: Stressors, resources, and definitions. Journal of Marriage and Family, 62(3), 655-668.

19. Williams, K., \& Umberson, D. (2004). Marital status, marital transitions, and health: A gendered life course perspective. Journal of Health and Social behavior, 45(1), 81-98. 